Turnip, BM. dan Siburian, TL.: Pengaruh Strategi Pembelajaran Fire-Up Terhadap Hasil Belajar Siswa Pada Materi Pokok Hukum Newton di Kelas VIII Semester I SMP PTP Nusantara IV Bah Jambi Tahun Pembelajaran 2011/2012

\title{
PENGARUH STRATEGI PEMBELAJARAN FIRE-UP TERHADAP \\ HASIL BELAJAR SISWA PADA MATERI POKOK HUKUM \\ NEWTON DI KELAS VIII SEMESTER I SMP PTP \\ NUSANTARA IV BAH JAMBI TAHUN PEMBELAJARAN 2011/2012
}

\author{
Betty M.Turnip dan Tommy Lesmana Siburian \\ Jurusan Pendidikan Fisika Universitas Negeri Medan
}

\begin{abstract}
Abstrak. Proses belajar mengajar selama ini hanya berpusat kepada guru, buku panduan siswa yang sedikit, tidak adanya perpustakaan di sekolah serta tidak adanya alat-alat praktikum untuk sebagian besar materi. Proses belajar mengajar Fisika di kelas berlangsung dengan mencatat dan mengerjakan soalsoal sehingga hasil belajar siswa selalu rendah. Maka dari itu penelitian ini dilakukan bertujuan untuk mengetahui pengaruh strategi pembelajaran FIREUP terhadap hasil belajar siswa pada materi pokok Hukum Newton di kelas VIII semester I SMP PTPN IV Bah Jambi Tahun Pembelajaran 2011/2012. Hasil penelitian menunjukkan rata-rata hasil postes pada kelas kontrol adalah 45,67 dengan simpangan baku 12,09 dan rata-rata hasil postes kelas eksperimen adalah 53,67 dengan simpangan baku 13,13. Selanjutnya dari hasil uji $\mathrm{t}$ satu pihak diperoleh $\mathrm{t}_{\text {hit }}=2,53$ serta harga $t_{\text {tabel }}=1,67$ pada taraf signifikan $\alpha=0,05 ; t_{\text {hitung }}>t_{\text {tabel }}$ sehingga dapat disimpulkan bahwa ada pengaruh strategi pembelajaran FIRE-UP terhadap hasil belajar siswa pada materi pokok Hukum Newton di kelas VIII semester I SMP PTPN IV Bah Jambi tahun pembelajran 2011/2012.
\end{abstract}

Kata kunci: strategi pembelajaran, fire-up, hasil belajar

\section{Pendahuluan}

Berdasarkan hasil wawancara yang dilakukan terhadap guru mata pelajaran Fisika yaitu ibu Ellyawati Lubis yang mengajar di SMP PTP Nusantara IV Bah Jambi, proses belajar mengajar selama ini hanya berpusat kepada guru, ditambah lagi kurangnya minat peserta didik, buku panduan siswa yang sedikit, tidak adanya perpustakaan di sekolah tersebut serta tidak adanya alat-alat praktikum untuk sebagian besar materi. Penulis juga membagikan angket kepada peserta didik lalu diketahui sebanyak $82 \%$ siswa menyatakan proses belajar mengajar Fisika di kelas berlangsung dengan mencatat dan mengerjakan soal-soal. Nilai ratarata peserta didik untuk mata pelajaran Sains yaitu 61,00 sedangkan untuk syarat ketuntasan belajar di sekolah tersebut adalah 61,00. Tetapi dari nilai rata-rata tersebut hanya sebagian kecil peserta didik yang mendapat nilai di atas nilai syarat kelulusan. Hal ini dibuktikan dari angket bahwa sebanyak $53 \%$ siswa mendapat nilai 5070. Menurut pengakuan ibu Ellyawati Lubis bahwa setiap nilai yang dilaporkan adalah nilai yang sudah diberi tambahan terutama untuk mata pelajaran Fisika.

\section{Hakekat Strategi Pembelajaran FIRE-UP}

Pembelajaran adalah suatu kegiatan yang dilakukan oleh guru sedemikian rupa, sehingga tingkah laku siswa berubah kearah yang lebih baik (Darsono, 2000). Ciri-ciri pembelajaran dapat dikemukakan sebagai berikut:

a. Pembelajaran dilakukan secara sadar dan direncanakan secara sistematis. 
b. Pembelajaran dapat menumbuhkan perhatian dan motivasi siswa dalam belajar.

c. Pembelajaran dapat menyediakan bahan belajar yang menarik dan menantang bagi siswa.

d. Pembelajaran dapat menggunakan alat bantu belajar yang tepat dan menarik.

e. Pembelajaran dapat menciptakan suasana belajar yang aman dan menyenangkan bagi siswa.

f. Pembelajaran dapat membuat siswa siap menerima pelajaran, baik secara fisik maupun psikologis (Darsono, 2000).

Strategi pembelajaran adalah suatu kegiatan pembelajaran yang harus dikerjakan guru dan siswa agar tujuan pembelajaran dapat dicapai secara efektif dan efisien (Sanjaya, 2008). Selanjutnya, Sanjaya mengemukkan bahwa dalam strategi pembelajaran terkandung makna perencanaan, artinya, strategi pada dasarnya masih bersifat konseptual tentang keputusan-keputusan yang akan diambil dalam suatu pelaksanaan pembelajaran.

Strategi pembelajaran sifatnya masih konseptual dan untuk mengimplementasikannya digunakan berbagai metode pembelajaran tertentu. Dengan kata lain, strategi merupakan $a$ plan of operation achieving something (Sanjaya, 2008).

Strategi pembelajaran FIRE-UP adalah metode belajar yang dipercepat dengan strategi yang memberi penekanan untuk mempengaruhi pola interaksi siswa yang melibatkan siswa dalam menelaah materi sebelum pelajaran dimulai yang diberikan sebagai tugas pengetahuan awal siswa (Ivone, 2002). Strategi pembelajaran FIRE-UP menitikberatkan pada usaha pengembangan keterampilan berpikir untuk memproses informasi yang berguna.

Langkah-langkah FIRE-UP (Ivone, 2002) berasal dari singkatan FIRE-UP yaitu: 1) $\mathrm{F}=$ Foundation/Fondasi, 2) I = Intake information/ Menyerap informasi, 3) $\mathrm{R}=$ Real meaning/ Makna yang sebenarnya, 4) $\mathrm{E}=$ Express your knowledge/Ungkapan, 5) $\mathrm{U}=$ Use available resources/Memanfaatkan sumber-sumber yang tersedia, 6) $\mathrm{P}=$ Plan of actioan/ Perencanaan tindakan.

Langkah-langkah pelaksanaan strategi pembelajaran FIRE-UP:

\section{1) Foundation/Fondasi}

Ada banyak cara yang membuat orang ingat. Fondasi memungkinkan kita mengetahui mengapa informasi yang kita pelajari dapat dengan mudah diingat kembali jika diperlukan. Setelah informasi fondasi atau dasar yang tersedia semakin banyak, kembalilah ke peta belajar kita untuk mengembangkan apa yang telah kita ketahui.

\section{2) Intake Information/Menyerap Informasi}

Kita akan menemukan gaya pilihan kita yang memungkinkan anda menyerap informasi secara visual, audio, atau kinestetis (melalui indera peraba). Melalui melihat apa yang sedang kita pelajari, indra gaya perasa dan pencium dapat ditambahkan dalam daftar cara belajar. Bagian ini berkonsentrasi pada cara kita memasukkan informasi. Pertama adalah melihat berbagai cara kita memperoleh informasi. Lalu lakukan penjajakan pribadi untuk menemukan preferensi yang membentuk gaya belajar kita.

3) Real Meaning/Makna yang Sebenarnya

Tidak ada pembelajar yang hanya menggunakan salah satu cara tersebut. Setelah menyelesaikan langkah Menyerap Informasi kita akan menemukan gaya serap utama kita. Kita juga akan memahami bagaimana menggunakan gaya-gaya lainnya untuk belajar lebih cepat dan lebih mudah. Proses tahap ketiga ini memberi kita peluang menciptakan makna yang sebenarnya untuk informasi baru yang baru saja kita serap. Ini dilakukan melalui proses yang disebut Asimilasi. Asimilasi adalah proses mengaitkan informasi baru ke dalam pengetahuan dasar yang dimiliki saat ini.

4) Express your knowledge/Ungkapkan Pengetahuan anda

Proses tahap keempat memberi kita peluang untuk Mengungkapkan Pengetahuan Kita yang baru kepada orang lain. Ketika kita menunjukkan bahwa kita tahu, kepercayaan diri kita akan semakin bertambah. Ketika kita mulai memperlihatkan bahwa anda tahu, tapi kemudian 
menyadari bahwa sebenarnya kita tidak tahu, mundurlah. Serap informasi itu dengan menggunakan cara belajar atau proses asmilasi lain.

5) Use available resources/Memanfaatkan
sumber-sumberyang tersedia
Proses kelima memungkinkan kita memanfaatkan pengetahuan yang baru ditemukan dengan berbagai cara. Kita juga akan belajar memanfaatkan orang lain dan sumber daya lain untuk meningkatkan keseluruhan proses belajar. Orang lain pernah berada posisi kita sekarang. Mereka juga telah mempelajari keterampilan atau aplikasi yang sedang kita pelajari, cara sebelum anda menggunakan pengetahuan baru adalah Memanfaatkan orangorang itu.

\section{6) Plan of Action/ Perencanaan Tindakan}

Merencanakan proses belajar ada dalam proses keenam. Perencanaan Tindakan akan didasarkan pada semua yang telah kita terapkan hingga poin ini. Pada akhir program, semua peta belajar akan membentuk dasar Perencanaan Tindakan Belajar yang disesuaikan dengan anda.

Penerapan strategi pembelajaran ini bertujuan untuk mengetahui pengaruhnya terhadap hasil belajar siswa. Hasil belajar merupakan kemampuan yang dimiliki siswa setelah menerima pengalaman belajar. Hasil belajar ini menurut Bloom diklasifikasikan menjadi tiga ranah yaitu kognitif, afektif dan psikomotor (Sudjana, 2002).

Hasil belajar adalah hasil yang telah dicapai oleh siswa dalam belajar. Hasil belajar juga merupakan berbagai kapasitas yang diperoleh siswa sehubungan dengan keikutsertaannya dalam proses pembelajaran. Disatu sisi hasil belajar merupakan pencapaian tujuan pengajaran, disisi lain hasil belajar merupakan penggal dan puncak belajar siswa (Dimyati dan Mudjiono, 1999).

Hasil belajar dipengaruhi oleh faktor intern dan faktor ekstern yang dialami dan dihayati siswa yang berpengaruh terhadap proses belajar adalah (1) sikap siswa terhadap belajar, (2) motivasi belajar, (3) konsentrasi belajar, (4) kemampuan mengolah bahan belajar, (5) kemampuan yang telah tersimpan, (6) kemampuan berprestasi atau unjuk hasil belajar, (7) rasa percaya diri siswa, intelegensia dan keberhasilan belajar dan kebiasaan belajar. Sedangkan faktor-faktor ekstern yang mempengaruhi hasil belajar antara lain: (1) guru sebagai pembimbing belajar siswa, (2) sarana dan prasarana belajar, (3) kondisi pembelajaran, (4) kebijakan penilaian, (5) kurikulum yang diterapkan dan lingkungan sosial siswa (Dimyati dan Mudjiono, 1999).

Pencapaian hasil belajar yang optimal dipengaruhi oleh beberapa faktor yaitu:

1. Kesiapan belajar. Kesiapan belajar merupakan kondisi awal suatu kegiatan belajar baik kesiapan fisik maupun psikologis.

2. Motivasi. Motivasi merupakan motif yang sudah menjadi aktif saat orang melakukan suatu aktivitas. Motif adalah kekuatan yang terdapat dalam diri seseorang yang mendorong orang tersebut melakukan kegiatan tertentu untuk mencapai tujuan.

3. Keaktifan siswa. Yang melakukan belajar adalah siswa sehingga siswa harus aktif dan tidak boleh pasif. Dengan bantuan guru siswa harus mampu mencari, menemukan, dan menggunakan pengetahuan yang dimilikinya.

4. Mengalami sendiri. Siswa hendaknya tidak hanya tahu secara teoritis, tetapi juga secara praktis sehingga akan diperoleh pemahaman yang mendalam.

5. Pengulangan. Agar materi semakin mudah diingat perlu diadakan latihan yang berarti siswa mengulang materi yang dipelajari.

6. Balikan dan Penguatan. Balikan adalah masukan yang sangat penting bagi siswa maupun guru. Penguatan adalah tindakan yang menyenangkan dari guru terhadap siswa yang telah berhasil untuk melakukan sesuatu perbuatan belajar (Darsono, 2000).

\section{Metode Penelitian}

Penelitian ini dilaksanakan pada siswa Kelas VIII semester I SMP PTPN IV Bah Jambi Tahun Pelajaran 2011/2012. Penelitian 
Turnip, BM. dan Siburian, TL.: Pengaruh Strategi Pembelajaran Fire-Up Terhadap Hasil Belajar Siswa Pada Materi Pokok Hukum Newton di Kelas VIII Semester I SMP PTP Nusantara IV Bah Jambi Tahun Pembelajaran 2011/2012

ini dilaksanakan pada bulan Agustus 2011. Dalam penelitian ini yang menjadi populasi adalah seluruh siswa yang belajar di Kelas VIII SMP PTPN IV Bah Jambi Tahun Pelajaran 2011/2012 yang terdiri dari 3 kelas. Sampel dalam penelitian ini terdiri dari dua kelas yaitu kelas kontrol dan kelas eksperimen ditentukan dengan teknik random sampling.

\section{Hasil Penelitian \\ Pelaksanaan Pretes}

Sebelum dilaksanakan pembelajaran dengan strategi pembelajaran FIRE-UP dan strategi pembelajaran konvensional maka terlebih dahulu dilakukan pretes yang bertujuan untuk mengetahui kemampuan awal siswa.

\section{Pelaksanaan Postes}

Setelah diberikan perlakuan pada masingmasing kelas, dilaksanakan postes untuk mengetahui hasil belajar siswa kelas eksperimen dan kelas kontrol.

\section{Pembahasan}

Pada awal penelitian masing-masing kelas diberikan pretes untuk mengetahui kemampuan awal siswa pada materi pokok hukum newton dari hasil pretes diperoleh hasil belajar siswa pada kelas kontrol yaitu dengan rata-rata 33,17 dan pada kelas eksperimen dengan rata-rata 37,17 . Kemudian dilakukan uji normalitas data penelitian dengan menggunakan uji Lilliefors dan nilai $\mathrm{L}_{\text {tabel }}=0,1610$. Hasil pengujian menunjukkan nilai pretes kedua kelompok sampel yaitu kelas eksperimen $0,1466<0,1610$ dan kelas kontrol 0,1439< 0,1610 atau $\mathrm{L}_{\text {hitung }}<\mathrm{L}_{\text {Tabel }}$ pada taraf signifikan 0,05 . Dengan demikian terbukti bahwa data pretes kedua kelompok sampel berdistribusi normal.

Uji Homogenitas data penelitian bertujuan untuk mengetahui apakah kedua sampel berasal dari populasi yang homogen atau tidak. Berdasarkan perhitungan hasil uji homogenitas pretes diperoleh nilai $\mathrm{F}_{\text {hitung }}=1,34$. Pada taraf signifikan 0,10 diperoleh harga $\mathrm{F}_{\text {Tabel }}=1,87$. Karena $\mathrm{F}_{\text {hitung }}<\mathrm{F}_{\text {Tabel }}$ maka data pretes kedua sampel homogen yang berarti data yang diperoleh dapat mewakili seluruh populasi yang ada.
Kemudian dilaksanakan proses kegiatan belajar mengajar di kelas VIII-2 sebagai kelas eksperimen dengan menggunakan strategi pembelajaran FIRE-UP. Kegiatan belajar mengajar dengan menggunakan strategi pembelajaran FIRE-UP melalui empat tahap yaitu:

1) Foundation/Fondasi :Dalam hal ini siswa akan mulai membangun pengetahuan awalnya dan mengingat mengenai materi pelajaran ketika guru melakukan tanya jawab.

2) Intake Information/Menyerap Informasi: Dengan melakukan demonstrasi sederhana tersebut siswa mempunyai informasi baru mengenai materi pelajaran yang sedang berlangsung yaitu berupa gejala-gejalanya. Hal tersebut karena siswa akan menyerap informasi secara visual,audio dan kinestetis (melalui indera peraba).

3) Real Meaning/Makna yang Sebenarnya: Pada tahap Real Meaning guru menerangkan materi pelajaran maka pada saat itu siswa mengaitkan atau menambahkan informasi yang diterima dari penjelasan guru ke dalam pengetahuan awal yang dimiliki siswa. Mulai dari pada saat guru melakukan apersepsi, informasi ketika siswa melakukan demonstrasi sederhana sehingga siswa mendapatkan makna sebenarnya dan memahami konsep dari materi yang diajarkan.

4) Express your knowledge/Ungkapkan Pengetahuan anda: Setelah siswa menerima informasi baru, guru membimbing siswa mengungkapkan pengetahuan baru mereka setelah mereka mengaitkan informasi kepada teman atau kelompok lainnya melalui presentasi singkat. Dalam hal ini siswa akan mengungkapkan pengetahuan yang diterimanya kepada temannya, hal ini berdampak positif untuk menambah kepercayaan dirinya.

5) Use available resources/Memanfaatkan sumber-sumber yang tersedia: Siswa berdiskusi dalam kelompoknya dan melakukan demonstrasi sederhana lagi guna menyimpulkan informasi dan mendapatkan inti dari materi pelajaran yang diajarkan. 
Dalam hal ini siswa harus memanfaatkan sumber yang ada sebagai bahan mereka, seperti buku bacaan, teman dan sumber lainnya. Dalam tahap ini siswa diharapkan untuk berdiskusi, memberikan pendapat karena teman-temannya pun dapat dimanfaatkan sebagai sumber informasi.

6) Plan of Action/Perencanaan Tindakan: Pada tahap ini guru bersama-sama dengan siswa menyimpulkan materi pelajaran. Yaitu dengan memberikan saran, dan memberikan informasi mengenai aplikasi dari materi yang diajarkan.

Setelah melaksanakan strategi pembelajaran FIRE-UP pada kelas eksperimen selama 3 pertemuan kemudian peneliti memberikan postes. Dari hasil postes pada kelas eksperimen diperoleh rata-rata 53,67. Hal tersebut menunjukkan peningkatan rata-rata hasil belajar kelas eksperimen.

Pada kelas kontrol yang menggunakan strategi pembelajaran konvensional yaitu pada kelas VIII-3. Setelah melakukan pretes, peneliti mulai untuk melakukan Tanya jawab, setelah itu menjelaskan materi tentang hukum Newton dengan metode ceramah lalu memberikan penugasan kepada siswa. Setelah selesai pembelajaran, peneliti memberikan postes. Dari hasil postes diperoleh nilai siswa pada kelas kontrol dengan rata-rata 45,67.

Pengujian hipotesis pada penelitian menggunakan taraf signifikansi $\alpha=0,05$ dan d.k $=58$, untuk pengujian postes diperoleh $t_{\text {hitung }}=2,53$ sedangkan $t_{\text {tabel }}=1,67$ sehingga diperoleh $t_{\text {hitung }}>t_{\text {tabel }}=2,53>1,67$. Dengan demikian adanya pengaruh strategi pembelajaran FIRE-UP terhadap hasil belajar siswa pada materi pokok Hukum Newton di kelas VIII Semester I SMP PTPN IV Bah Jambi secara statistik teruji kebenarannya.

Jika pada penelitian sejenis terdahulu (Mediace, 2010) dalam proses tahapan FIREUP tidak menggunakan demonstrasi dalam proses Real Meaning. Sehingga dalam penelitian tersebut tidak dapat menunjukkan secara real tentang pemecahan masalah dalam materi yang diajarkan. Berbeda pada penelitian ini, setiap tahapan pada prosees FIRE-UP dilakukan secara lengkap dengan dilakukan demonstrasi pada proses Real Meaning, sehingga siswa dirangsang untuk mendapatkan informasi baru pada saat materi diajarkan sebagai untuk menambah pengetahuan dasar siswa tersebut.

Strategi belajar FIRE-UP adalah metode belajar yang dipercepat dengan strategi yang memberi penekanan untuk mempengaruhi pola interaksi siswa yang melibatkan siswa dalam menelaah materi sebelum pelajaran dimulai sebagai pengetahuan awal siswa. Strategi FIRE-UP menitikberatkan pada usaha pengembangan keterampilan berpikir untuk memproses informasi baru yang berguna.

\section{Simpulan}

Kesimpulan penelitian ini didasarkan pada hasil penelitian, sistematika sajiannya dilakukan dengan memperhatikan tujuan penelitian yang telah dirumuskan. Adapun kesimpulan yang diperoleh antara lain: Hasil belajar Fisika siswa yang diberi strategi pembelajaran FIRE-UP pada materi pokok Hukum Newton di kelas VIII semester I SMP PTPN IV Bah Jambi Tahun Pelajaran 2011/ 2012 sebelum diberikan perlakuan rata-rata pretes sebesar 37,17 dan setelah diberi perlakuan dari hasil postes diperoleh rata-rata hasil belajar siswa sebesar 53,67. Sementara hasil belajar Fisika siswa yang diberi pembelajaran konvensional sebelum diberikan perlakuan rata-rata pretes sebesar 33,17 dan setelah diberi perlakuan dari hasil postes diperoleh rata-rata hasil belajar siswa sebesar 45,67. Ada pengaruh strategi pembelajaran FIRE-UP terhadap hasil belajar siswa pada materi pokok Hukum Newton di kelas VIII semester I SMP PTPN IV Bah Jambi dengan $t_{\text {hitung }}>t_{\text {tabel }}=2,53>1,67$.

Berdasarkan hasil penelitian dan kesimpulan di atas, maka sebagai tindak lanjut dari penelitian ini disarankan beberapa hal sebagai berikut: Bagi siswa, khususnya siswa SMP PTPN IV Bah Jambi hendaknya selalu melakukan persiapan belajar dan lebih aktif dalam setiap kegiatan pembelajaran agar diperoleh hasil yang lebih baik. Bagi peneliti 
Turnip, BM. dan Siburian, TL.: Pengaruh Strategi Pembelajaran Fire-Up Terhadap Hasil Belajar Siswa Pada Materi Pokok Hukum Newton di Kelas VIII Semester I SMP PTP Nusantara IV Bah Jambi Tahun Pembelajaran 2011/2012

selanjutnya diharapkan untuk meneliti dengan mencari alternatif lain dalam strategi pembelajaran FIRE-UP agar tercapai waktu yang efisien dalam proses pembelajaran sehingga meningkatkan kualitas dan kuantitas siswa dalam mata pelajaran Fisika.

\section{DAFTAR PUSTAKA}

Darsono, M. 2000. Belajar dan Pembelajaran. Semarang: IKIP Semarang Press.

Dimyati dan Mudjiono.1999. Belajar dan Pembelajaran. Jakarta: Rineka Cipta.

Ivone, S. 2002. FIRE-UP Your Learning Tingkatkan Ranking Anda. Jakarta: Penerbit Gramedia.

Sanjaya, W. 2008. Strategi Pembelajaran. Jakarta: Kencana.

Sudjana, N. 2002. Dasar-Dasar Proses Belajar Mengajar. Bandung: Algesindo. 